\title{
THE EFFECT OF PULMONARY ISCHAEMIA ON LUNG FUNCTION
}

\author{
BY \\ H. W. HANKINSON AND F. RONALD EDWARDS \\ From the Department of Thoracic Surgery, University of Liverpool
}

(RECEIVED FOR PUBLICATION NOVEMBER 12, 1958)

The blood supply of living tissue can be cut off for varying lengths of time without permanent damage to function, depending upon the complexity of the tissue involved. Ischaemia of the brain produces permanent damage in a few minutes, but ischaemia of voluntary muscle can be tolerated for two to three hours. In our experience the human heart will restart and function normally after the coronary supply has been cut off for 30 minutes. A study of the effects of ischaemia on dog lung was made by Blades (1954 ; Blades, Beattie, Hill, and Thistlethwaite, 1952 ; Blades, Pierpont, Samadi, and Hill, 1954), and he gave his view that after 30 minutes of ischaemia severe permanent effects on pulmonary function were likely, although viability of the lung was possible even after six hours' occlusion. Under certain emergency operative conditions the blood supply of the lung has been totally interrupted by us for longer than 30 minutes without any apparent permanent effects upon function, and it seemed that further investigation of the time of permissible ischaemia of the lung might be of value.

Although the lung has a dual blood supply it is difficult to determine to what extent persistence of pulmonary function depends upon each. Certain clinical observations, however, may be valuable in assessing this factor.

Under the circumstances of congenital atresia of the pulmonary artery, after closure of the ductus, the bronchial arteries and other systemic vessels become greatly enlarged and communicate extensively with the alveolar vascular system. The blood that passes through is satisfactorily oxygenated, albeit only a small percentage of the total cardiac output. It appears, therefore, that a pulmonary arterial flow is not essential for maintenance of the alveolar oxygenating function of the lung.

Some 12 years ago one of us (F. R. E.) ligated the ipsilateral pulmonary artery in a series of patients with irremovable carcinoma of the lung. This was undertaken to study whether such a $\vec{N}$ procedure would slow up the growth of the $\circ$ neoplasm. No evidence was forthcoming that in fact it did so, but radiologically the lung remained $\vec{c}$ fully expanded and aerated. No case developed any obvious massive fibrosis of the lung, neither did any gangrene develop, although pulmonary $\overrightarrow{\mathcal{O}}$ collapse supervened later in some cases as the $\subseteq$ tumour obstructed the bronchi. It appears that the adult lung can remain viable on the normal bronchial arterial communications with the general pulmonary circulation. That this supply is a precarious one, in an infant at any rate, is $\stackrel{\mathbb{Q}}{\mathcal{D}}$ shown by a case of atrial septal defect with total $\overrightarrow{\vec{A}}$ anomalous venous drainage of the right lung into $\frac{9}{3}$ the inferior vena cava. Following closure of the atrial septal defect it was decided to ligate the right pulmonary artery as anatomically it was impossible to anastomose the large single pulmonary vein into the left atrium. This was an $\underset{\sim}{x}$ error of judgment, and a pneumonectomy should $\dot{\sigma}$ have been performed, for gangrenous changes 3 . supervened in the lung.

In plastic operations upon the bronchus with removal of the upper lobe and re-anastomosis of $\frac{\mathrm{f}}{2}$ the lower lobe to the stump of the main $\rightarrow$ bronchus, the bronchial arterial supply is frequently sacrificed. This does not appear to have any serious effect upon the bronchus itself or $\Omega$ the lung.

From these clinical observations it may be assumed that the lung will, in general, go on living with only one of the two circulations intact. Functional studies are not available.

Under the following conditions it may be necessary to occlude both pulmonary circulations 7 for a period of time.

(1) To secure a bloodless field when faced with a difficult situation in dealing with benign or malignant lesions. Haemorrhage due to tearing a large vessel during dissection or a difficult transplantation of a lobar bronchus is an example 
in point, and the application of a hilar clamp may be required. Hilar clamping may also considerably facilitate the dissection of an arteriovenous fistula of lung.

(2) In the treatment of anomalous pulmonary venous drainage with transplantation of the veins into the left atrium, simple temporary ligation of the pulmonary artery without occlusion of the bronchial supply is inadvisable as there is a danger of severe interstitial haemorrhage within the lung.

(3) In operations for anomalous pulmonary venous drainage and transposition of the great vessels' when the pulmonary veins have to be anastomosed to the atrium, temporary occlusion of the vein for any length of time is inadvisable, even though the pulmonary artery is occluded. Interstitial pulmonary haemorrhages from the bronchial arteries are frequent after a short period of time. If the bronchial system can also be occluded then the blood loss from leaving the veins open can be reduced.

(4) During the use of a cardio-pulmonary by-pass, much of the intracardiac blood loss arises from the bronchial arterial flow, which may be reduced by bilateral hilar clamping.

\section{EXPERIMENTAL STUDY}

The experiments were divided into three stages, and the method of taking the procedure to the stage of ultimate survival of the animal on the one lung previously rendered ischaemic, as suggested by Blades, was adopted. Twenty-four surgical interventions were performed on 16 mongrel dogs. Anaesthesia was induced with $2 \frac{1}{2} \%$ pentothal intravenously; a cuffed endotracheal tube was inserted, and ventilation maintained with a manually compressed bag using oxygen and with occasional admissions of air. A carbon dioxide absorber was in circuit.

StaGe I.-Via a thoracotomy the hilum of the left lung was clamped with a Crafoord's coarctation clamp tightly enough to occlude all vascular structures. Vascular occlusion periods of threequarters of an hour, one hour, one and a quarter hours, one and a half hours, one and three-quarter hours, two hours, and two and a half hours were used in different animals. Samples of blood were taken from the pulmonary artery and pulmonary veins, before and five minutes after release of the clamp. Care was taken not to obtain atrial blood at the pulmonary vein puncture by temporarily obstructing the venous ostium into the atrium with a clamp.

The oxygen content of the blood samples was estimated by Van Slyke's method.

The results are set out in Table I.

Some anaesthetic difficulties were encountered during this series of experiments, but it will be seen that the dogs who were submitted to unilateral hilar occlusion up to $105 \mathrm{~min}$. recovered satisfactorily. Of the seven dogs who had occlusion for two hours or more only two recovered. Three of the deaths of this latter series were due to an oedema of the left lung occurring immediately after release of the clamp. This produced flooding of the bronchial tree with a thin blood-stained secretion uncontrollable by suction. Presumably the alveolar capillary permeability had been grossly altered by the length of time of the anoxia.

The ability of the occluded lung to oxygenate blood after release of the clamp appeared to remain reasonably satisfactory up to a period of two hours. The animals were, however, receiving a high percentage of oxygen in the anaesthetic apparatus under positive pressure, and it was probable that some gaseous exchange could take place across the alveoli under oedemic conditions until the exuded fluid in the bronchioles eventually "drowned" the alveoli.

Stage II.-Out of the 16 original dogs, eight survived and were well enough to undergo the subsequent stage. In addition to the five dogs that died at the end of the operation, one dog died 48 hours after operation from pneumonia and two were sacrificed because of distemper (three days) and leptospirosis (15 days).

Survivors of stage I were submitted after an interval of three to four weeks to removal of the right lung, permitting them to live only upon the lung which had previously been rendered temporarily ischaemic.

TABLE I

EXPERIMENTAL RESULTS IN DOGS

\begin{tabular}{|c|c|c|c|c|c|c|}
\hline \multirow{3}{*}{$\begin{array}{l}\text { Dog } \\
\text { No. }\end{array}$} & \multirow{2}{*}{\multicolumn{2}{|c|}{$\begin{array}{c}\begin{array}{c}\text { Blood Oxygen } \\
\text { before } \\
\text { Occlusion }\end{array} \\
\text { Vol. } \%\end{array}$}} & \multirow{3}{*}{$\begin{array}{l}\text { Length } \\
\text { of } \\
\text { Time } \\
\text { of } \\
\text { Oc- } \\
\text { clusion } \\
\text { (min.) }\end{array}$} & \multirow{2}{*}{\multicolumn{2}{|c|}{$\begin{array}{c}\begin{array}{c}\text { Blood Oxygen } \\
\text { after } \\
\text { Occlusion }\end{array} \\
\text { Vol. } \%\end{array}$}} & \multirow{3}{*}{ Observations } \\
\hline & & & & & & \\
\hline & Artery & Vein & & Artery & Vein & \\
\hline $\begin{array}{l}1 \\
2 \\
3\end{array}$ & $\begin{array}{l}14 \cdot 92 \\
13 \cdot 40 \\
12 \cdot 64\end{array}$ & $\begin{array}{l}17 \cdot 56 \\
18 \cdot 36 \\
18 \cdot 72\end{array}$ & $\begin{array}{l}45 \\
60 \\
60\end{array}$ & $\begin{array}{l}14 \cdot 32 \\
14 \cdot 61 \\
14 \cdot 82\end{array}$ & $\begin{array}{l}18 \cdot 94 \\
17 \cdot 86 \\
18 \cdot 46\end{array}$ & $\begin{array}{l}\text { Satisfactory recovery } \\
\text {," } \\
\text { Recovered conscious- } \\
\text { ness but developed } \\
\text { laryngeal spasm } \\
\text { and died } 1 \text { hr. later }\end{array}$ \\
\hline $\begin{array}{l}4 \\
5 \\
6 \\
7 \\
8\end{array}$ & $\begin{array}{l}12 \cdot 75 \\
14 \cdot 95 \\
12 \cdot 74 \\
13 \cdot 92 \\
13 \cdot 89\end{array}$ & $\begin{array}{l}16 \cdot 92 \\
16 \cdot 70 \\
18 \cdot 92 \\
17 \cdot 47 \\
18 \cdot 79\end{array}$ & $\begin{array}{l}75 \\
75 \\
90 \\
90 \\
90\end{array}$ & $\begin{array}{l}13 \cdot 85 \\
13 \cdot 85 \\
13.46 \\
13.41 \\
15 \cdot 62\end{array}$ & $\begin{array}{l}18 \cdot 44 \\
1688 \\
17 \cdot 62 \\
17 \cdot 02 \\
19 \cdot 41\end{array}$ & $\begin{array}{cc}\text { Satisfactory } & \text { recovery } \\
,, & , \\
\text {," } & , \\
\text { Satisfactory recovery; } \\
\text { sacrificed } & 15 \text { th day }\end{array}$ \\
\hline $\begin{array}{r}9 \\
10\end{array}$ & $\begin{array}{l}14.22 \\
13.62\end{array}$ & $\begin{array}{l}18 \cdot 92 \\
18 \cdot 20\end{array}$ & $\begin{array}{l}105 \\
120\end{array}$ & $\begin{array}{l}14.84 \\
12.46\end{array}$ & $\begin{array}{l}17 \cdot 44 \\
18 \cdot 16\end{array}$ & $\begin{array}{l}\text { Satisfactory recovery } \\
\text { Satisfactory recovery. } \\
\text { Dog killed } 3 \text { days } \\
\text { later-distemper }\end{array}$ \\
\hline $\begin{array}{l}11 \\
12\end{array}$ & $\begin{array}{l}13.64 \\
14.62\end{array}$ & $\begin{array}{l}17 \cdot 84 \\
18 \cdot 66\end{array}$ & $\begin{array}{l}120 \\
120\end{array}$ & $\begin{array}{r}6 \cdot 24 \\
1224\end{array}$ & $\begin{array}{l}11.46 \\
14 \cdot 24\end{array}$ & $\begin{array}{l}\text { Dog died } 15 \mathrm{~min} \text {. } \\
\text { Dog recovered well } \\
\text { but died } 48 \mathrm{hr} \text {. later } \\
\text { - pneumonia }\end{array}$ \\
\hline $\begin{array}{l}13 \\
14 \\
15\end{array}$ & $\begin{array}{l}14.92 \\
13.24 \\
14.62\end{array}$ & $\begin{array}{l}16 \cdot 57 \\
17 \cdot 68 \\
17 \cdot 64\end{array}$ & $\begin{array}{l}120 \\
120 \\
150\end{array}$ & $\begin{array}{r}15 \cdot 27 \\
14.48 \\
2.74\end{array}$ & $\begin{array}{r}17 \cdot 29 \\
17 \cdot 52 \\
4 \cdot 26\end{array}$ & $\begin{array}{l}\text { Dog died } 6 \mathrm{hr} \text {. } \\
\text { Satisfactory recovery } \\
\text { Dog died } 5 \text { min. after } \\
\text { release of clamp. } \\
\text { Massive pulmnnary } \\
\text { oedema }\end{array}$ \\
\hline 16 & $13 \cdot 56$ & $16 \cdot 24$ & 150 & - & - & $\begin{array}{l}\text { Dog died suddenly at } \\
2 \frac{1}{2} \mathrm{hr} \text {. due to defect } \\
\text { in a na es thet ic } \\
\text { machine }\end{array}$ \\
\hline
\end{tabular}


A right pneumonectomy was performed on these residual eight dogs and two died post-operatively, one from a pre-existing undiagnosed pneumonia and one from a bronchial leak.

Six dogs finally survived the two stages and lived for a period of three months on the lung which had been rendered ischaemic, one dog each of the periods three-quarters of an hour, one hour, one and a quarter hours, one and a half hours, one and three quarter hours, and two hours' ischaemia. These six survivors showed no weight loss, had satisfactory appetites, and were able to continue their normal activity once the post-operative stage had been passed. There was no gross clinical evidence of impairment of lung function although we unfortunately had not the facilities to obtain any scientific data to establish whether this was significantly greater than was to be expected after a normal pneumonectomy.

The surviving six dogs were finally sacrificed at the end of three months. The residual left lungs which had been submitted to ischaemia showed in all cases a certain degree of pleural thickening with adhesion to the site of incision. The lungs in all dogs appeared to be well aerated with no superficial evidence of areas of collapse or infarction. They were all entrusted to Dr. F. Whitwell, pathologist to the Liverpool Thoracic Surgical Unit, for his macroscopic and histological findings. He reported no evidence of abnormality in the vessels major or minor, the bronchi, or the alveolar structure. In none of the lungs was there evidence of thrombosis or infarction even after two hours of complete vascular occlusion, nor was there any suggestion of necrotic foci.

\section{CONCLUSIONS}

The number of experiments is not great, due particularly to some anaesthetic difficulties in the early stages of the investigation, but evidence is $\stackrel{\overrightarrow{\bar{A}}}{\mathrm{~A}}$ presented that total ischaemia of the lung can be 0 tolerated without severe impairment of function $\underline{ }$ for a longer period than the 30 minutes suggested $\frac{\bar{\sigma}}{\frac{5}{\sigma}}$ by Blades. The onset of a very rapid pulmonary ${ }_{\alpha}$ oedema in some of the lungs that had been rendered ischaemic for two hours or more indicates that this period is beyond the permissible? limit.

Although the application of animal experiments to humans must be accepted with some reserve, $\overrightarrow{\vec{x}}$ it is probable that the lung can be rendered ischaemic for one hour and possibly a little longer $\vec{i}$ without obvious functional damage, thus permitting the surgical procedures cited at the $N$ beginning of this paper to be undertaken with을 greater leisure.

\section{SUMmARY}

In dogs one lung was rendered totally ischaemic $\stackrel{\overparen{D}}{\stackrel{\oplus}{ }}$ for periods of half to two and a half hours, and 0 the oxygenating function studied at the end of this period.

In surviving dogs, the contralateral lung was removed after a period and the animal allowed to recover and live on the lung previously rendered ischaemic.

Total ischaemia of the lung appears to be $\overrightarrow{\vec{O}}$ tolerated for a period of at least one hour without obvious permanent loss of pulmonary function.

\section{REFERENCES}

Blades, B. (1954). A.M.A. Arch. Surg., 69, 525

- Beattie, E. J., Hill, R.P., and Thistlethwaite, R. (1952). Ann. Surg., 136, 56.

Pierpont, H. C., Samadi, A., and Hill, R. P. (1954). Surg.

Forum, 1953, 4, 255. 